\title{
Kanaat Önderleri Olarak Köşe Yazarlarının Twitter Kullanımları
}

\section{Turan Ulaş}

\section{ÖZ}

Kanaat önderi kavramı, bir bireyin fikir ve görüşleriyle diğer bireylerin tutum ve davranışları üzerinde etkili olmasını ifade eder. Kamuoyu oluşumunda, toplumsal bilincin sağlanmasında önemli bir işlevi yerine getiren köşe yazarları ise dile getirdikleri fikirleriyle okuyucu/takipçi/izleyicilerin görüş ve düşüncelerinin oluşmasında etkili olan kanaat önderlerinin başında gelmektedir. Özellikle, Facebook, Twitter gibi sosyal ağlar vasıtasıyla köşe yazarlarının takipçileriyle yüksek etkileşimli bir alanda daha aktif iletişim kurabilme imkânına kavuşması, kanaat önderleri olarak önemlerini daha da artırmıştır. Bu bağlamda yapılan çalışmada, Türkiye'de kanaat önderleri olarak köşe yazarlarının Twitter'ı nasıl, ne şekilde, ne gibi işlevlerle ve hangi temel konular çerçevesinde kullandıklarının tespit edilmesi amaçlanmıştır. Amaçlı örnekleme yöntemlerinden tipik durum örneklemesi kullanılarak seçilen 5 köşe yazarının 01.12.2020-31.01.2021 tarihleri arasındaki Twitter paylaşımları içerik analizi yöntemiyle incelenmiştir. Çalışma sonunda köşe yazarlarının Twitter'ı, çevrimiçi ortamlardaki köşe yazılarına link vermek için sıklıkla kullandığı görülmüştür. Bulgular, köşe yazarlarının kendi çalıştığı gazete dışında profesyonel olan diğer medya kuruluşları ve çeşitli kaynaklardan da yararlandıklarını göstermektedir. Ayrıca, köşe yazarlarının çeşitli kaynaklardan elde ettikleri haber, bilgi ve görüşlere olumlu veya olumsuz düşüncelerini ekleyerek takipçileriyle paylaştıkları tespit edilmiştir. Bu durum köşe yazarlarının, kanaat önderleri olarak "News Curation" yöntemine yöneldiklerine işaret etmektedir.

Anahtar Sözcükler: Kanaat Önderleri, Twitter, Köşe Yazarları, Etkileşim, Etki

\author{
TURAN ULAŞ \\ Arş. Gör. \\ Yozgat Bozok Üniversitesi \\ turan.ulas@yobu.edu.tr \\ ORCID ID: 0000-0003-3829-9450
}

SELÇUK ILETIŞIM DERGISI 2021; 14(3): 1433-1463

doi: 10.18094/ JOSC.928358

Geliş Tarihi: 26.04.2021 Kabul Tarihi: 08.07.2021 Yayın Tarihi: 25.07.2021 


\title{
The Usage of Twitter by Columnists as Opinion Leaders
}

\section{Turan Ulaş}

\section{ABSTRACT}

The concept of opinion leader refers to the influence of an individual's ideas and views on the attitudes and behaviors of other individuals. Columnists, who fulfill an important function in forming public opinion and raising social awareness, are opinion leaders effective in forming the views and thoughts of readers/followers/viewers with their ideas. Especially, having the opportunity to communicate more actively with their followers in highly interactive social networks such as Facebook and Twitter has further increased the importance of columnists. This study aims to determine how columnists use Twitter as opinion leaders in Turkey, with what functions and within the framework of which basic topics. Twitter shares of 5 columnists between 01.12.2020-31.01.2021 selected using typical case sampling from purposive sampling methods were analyzed by content analysis method. The study concluded that columnists frequently use Twitter to link to their online columns. Findings show that columnists also benefit from other professional media organizations and various sources apart from the newspaper they work for. In addition, columnists share the news, information, and opinions they obtain from various sources with their followers by adding their positive or negative thoughts. This indicates that the columnists, as opinion leaders, turn to the "News Curation" method.

Keywords: Opinion Leaders, Twitter, Columnists, Interaction, Effect

\author{
TURAN ULAŞ \\ Res. Ass. \\ Yozgat Bozok University \\ turan.ulas@yobu.edu.tr \\ ORCID ID: 0000-0003-3829-9450
}

JOURNAL OF SELÇUK COMMUNICATION 2021; 14(3): 1433-1463

doi: 10.18094/ JOSC.928358 


\section{Giriş}

Kanaat önderi kavramı, 1940'lı yıllardan itibaren araştırmacıların üzerinde durdukları temel konulardan biri olmuştur. Toplumsal etkileşimde önemli bir kavram olan kanaat önderi anlayışının temelinde Lazarsfeld, Berelson ve Gaudet'ın yaptığı çalışmalar bulunmaktadır. Lazarsfeld ve arkadaşları, iki aşamalı akış kuramıyla birlikte kitle iletişim araçlarının bireyler üzerinde sanıldığı kadar sınırsız bir etkiye sahip olmadığı görüşünü öne sürmüşlerdir. İki aşamalı akış kuramına göre, toplumda kanaat önderi olarak rol oynayan kişiler, kitle iletişim araçlarından elde ettikleri bilgi ve düşünceleri, fikir süzgeçlerinden geçirdikten sonra kendilerinden etkilenen toplumun daha az aktif kesimlerine aktarırlar (1948, s. 151). Kanaat önderlerini tüm meslek gruplarında gözlemlemek mümkündür. Bu kişiler, siyasi konulara daha fazla ilgili olduklarından, diğer bireylere nazaran politik konularda daha fazla bilgi edinme gereksiniminde bulunurlar ve bu nedenle kitle iletişim araçlarındaki içeriğe daha fazla maruz kalma eğilimindedirler (s. 50-51).

Günümüzde gelişen ve toplumda kullanımı oldukça yaygınlaşan sosyal paylaşım ağları, bireylerin kanaat önderleri olarak hareket etmelerine, tartışma alanları oluşturmalarına ve çeşitli konularda fikirlerini beyan ederek toplumsal meselelerde etkili olmalarına olanak sağlamıştır. Ayrıca, kanaat önderleri tarafından günün haberlerinin bu alanlarda paylaşıması, çeşitli olay ve olguların daha geniş ağlarda tartışılmasına da olanak vermiş̧tir (Oeldorf-Hirsch \& Sundar, 2015, s. 240). Sosyal paylaşım ağları içerisinde Twitter ise diğer ağlardan farklı birtakım özellikleri itibariyle ayrı bir konuma sahiptir. Twitter'ın damıtık içeriğe sahip olması ve sınırlı kelime sayısıyla paylaşım yapmaya imkân vermesi onu, sosyal paylaşım ağları içerisinde daha güçlü bir konuma getirmektedir. Bu sayede Twitter'da paylaşılan iletiler, “... hem daha hızlı alımlanmakta hem de ağ içindeki etkisi daha büyük olmaktadır. Bu özelliği dolayısıyla Twitter, gazeteciler gibi belli meslek gruplarınca yoğun şekilde kullanılırken, yönetici siyasetçilerin tweetleri anında küresel tepki ile karşılanmaktadır" (Hülür \& Yaşın, 2019a, s. 21). Bu çerçevede kullanıcıların paylaşılan içeriklere kolay bir şekilde ulaşılabilmesi, yorum yapılabilmesi, tartışmalara katılabilmesi gibi özellikleri itibariyle Twitter, bireylerin tutum ve davranışlarının şekillenmesinde etkili olan kanaat önderlerinin faaliyet gösterdiği önemli bir alan olarak değerlendirilmektedir.

Köşe yazarları, kamuoyu oluşturabilme ve kamuoyunu yönetebilme açısından etkili bir güç olmaları (Altınoklu Şenay, 2016, s. 122) nedeniyle kanaat önderleri olarak önemli bir misyonu yerine 
getirmektedirler. Oluşturdukları içeriklerle eleştirel düşünmenin gelişmesini sağlayan köşe yazarları (Bohórquez-Pereira, Espinel, \& Mojica, 2020, s. 85), sosyal ağlarda oluşturdukları içeriklerle de bireylerin görüş ve düşüncelerinin şekillenmesinde önemli rol oynamaktadırlar. Toplumun kanaatlerinin şekillenmesinde etkili olan köşe yazarlarının, sosyal paylaşım ağlarında paylaştıkları içerikleri ve bu ağlarda gerçekleştirdikleri faaliyetleri incelemek, önemli bir konuyu aydınlatacaktır. Bu çerçevede çalışmanın temel amacı, Türkiye'de köşe yazarlarının Twitter'ı nasıl, ne şekilde, hangi işlev ve konular için kullandıklarını tespit etmektir. Türkiye'de basılı gazetelerde köşe yazarlı̆̆ı alanında faaliyet gösteren kişiler arasından amaçlı örnekleme yöntemlerinden tipik durum örneklemesiyle seçilmiş 5 köşe yazarının, 01.12.2020-31.01.2021 tarihleri arasındaki Twitter paylaşımları niceliksel içerik analizi yöntemiyle incelenmiştir. İçerik analizinde Noguera Vivo (2013, s. 107-109) ile Marcos-García, Alonso-Munoz ve Lopez-Meri'nin (2020, s. 281-283) geliştirdiği kategoriler kullanılmıştır. Veriler, SPSS 22 programı aracılığıyla analiz edilmiştir.

\section{“KANAAT ÖNDERI" KAVRAMI}

Toplumsal ilişkiler ağında bireylerin saygı duyduğu, görüşlerine önem verdiği, davranışlarının ve fikirlerinin şekillenmesinde etkili olan bireyleri ifade eden "kanaat önderi" kavramı, 1940'ı yıllardan itibaren araştırmacıların sıklıkla üzerinde durduğu konulardan biri olmuştur. Kavramın kökenleri, Lazarsfeld, Berelson ve Gaudet (1948) tarafından, bireylerin oy verme davranışları üzerine gerçekleştirdikleri çalışmalara dayanmaktadır. Özellikle bu dönemden itibaren iki aşamalı akış kuramı üzerine yapılan çeşitli çalışmalar göstermiştir ki, kitle iletişim araçları toplum üzerinde sanıldığı kadar güçlü etkilere sahip değildir ve medya, bireyler üzerinde tahmin edilenden daha düşük düzeyde bir etkiye sahiptir (Katz, 1957).

Kanaat önderleri, bazen bir lider olarak rol oynadıklarının farkında olmadan arkadaş grupları, aile ve komşuluk gibi sıradan, samimi yakın ilişikler sırasında ortaya çıkarlar. Onlar, günlük ilişkilerde gayri resmi bir şekilde yer alırlar, sıradan ilişkiler sırasında görünmez bir biçimde faaliyet gösterirler (Katz \& Lazarsfeld, 1955, s. 138). Kanaat önderleri, lider olarak görüldükleri kişiler tarafından belirli bir konuda uzmanlığına güvenilen ve bilgili oldukları düşünülen kişilerdir (Weimann, Tustin, Van Vuuren, \& Joubert, 2007, s. 174). 
Rogers (2003) ise kanaat önderliğini, bir bireyin diğer bireylerin tutumlarını veya davranışlarını etkileyebilme derecesi olarak tanımlamıştır. Kanaat önderleri, etkiledikleri kişiler ile karşılaştırıldığında daha fazla dış iletişime maruz kaldıklarından dolayı daha kozmopolittirler, takipçilerinden daha yüksek sosyal statüye sahiptirler ve onlardan daha yenilikçidirler (s. 27-28). Kanaat önderlerinin toplumdaki en önemli rollerinden birinin "...arkadaş çevreleri için siyasi konuları vurgulayarak, tanımlayarak ve çerçevelendirerek kamuoyu oluşumuna" katkı sağlamaları olduğunu ifade eden Tsang ve Rojas (2020), özellikle bireylerin kendilerini kanaat önderi olarak tanımladıkları süreç içerisinde, politik konuları tartışma ve siyasete katılma olasılıklarının arttığına dikkat çekmektedir. Arkadaş çevreleri arasında daha yenilikçi oldukları düşünülen, yani kanaat önderi olarak ifade edilebilen bireyler, "siyasi etkinliklere (mitingler, protestolar ve şehir toplantıları vb.) katılma ve siyasi faaliyette bulunmada (dilekçe imzalama, para bağışlama ve gönüllülük vb.) daha aktif" olmaktadırlar (s. 753, 763).

\section{ILETişiM SÜRECINDE TWITTER}

Twitter, 2006 yllında kurulan ve günümüzde 280 karakter limitiyle "tweet" ismi verilen gönderiler paylaşmaya imkân veren bir sosyal paylaşım ağıdır. Twitter'da paylaşılan içerikler herkese açık tweetler (Twitter hesabı olan veya olmayan herkes tarafından görülebilir) ya da korumalı Tweetler olarak (Tweetler yalnızca Twitter kullanııılarının takipçileri tarafından görülebilir) düzenlenebilmektedir (Herkese açık ve korumalı tweetler hakkında, 2021). Twitter'ın 280 karakterlik kısa mesajlar gönderilmesine izin vermesiyle kullanıcılar, içerik oluşturmada esnek, etkileşim düzeyi yüksek ve hızlı bir iletişim süreci içerisinde bulunabilmektedir (Park, 2013, s. 1642).

Günümüzde siyasal iletişim açısından önemli bir yerde konumlanan Twitter, geleneksel iletişim araçlarından farklı olarak 'etkileşimli iletişime' imkân sağlamasıyla ön plana çıkmaktadır. Ayrıca Twitter, toplumdaki herkese fikirlerini açıklayabilme ve katılım imkânı vermesiyle fırsat eşitliği sunmakta, topluluklar oluşturarak organize olma imkânı vermekte ve çeşitli verilerin analizi yoluyla (duygu analizi vb.) siyasal kampanya stratejilerini yönetenlere iletişim stratejilerini geliştirmek için birtakım avantajlar sağlamasıyla da siyasal iletişim süreçlerini etkilemektedir (Eren, 2015, s. 21-27).

Twitter gibi sosyal paylaşım ağlarının toplumdaki önemli bir rolü de kamuoyu oluşum sürecinde etkili olmalarıdır. Toplumsal yaşamın bir çeşit simülasyonu diyebileceğimiz sosyal ağlar, gerçek yaşamı 
taklit eden bir yapıya sahip olduğundan kamuoyu oluşum sürecini etkilemektedir. Lâkin, gerçekteki toplumsal yaşamdan farklı olarak sosyal paylaşım ağlarındaki kamuoyu oluşumu, çok kısa zaman dilimleri içerisinde meydana gelmektedir (Yengin \& Bayrak, 2017, s. 382).

Başta gazeteciler ve siyasetçiler olmak üzere çeşitli mesleklerden kişiler tarafından yoğun bir şekilde kullanılan Twitter, yeni bir haber mecrası olarak işlevsel bir özellik kazanmış, politik süreçlerde aktif rol oynayan bir iletişim ağı konumuna gelmiştir. Tüm dünyada geniş bir kullanım oranına sahip olan Twitter, "... retorik temelinde kurgulanmış bir iletişim platformudur. Öne çıkartmış olduğu retoriğe, az sayıda kişinin değil geniş bir kitlenin katılmasını sağlayan Twitter, bir bakıma düşüncenin kamusallaşmasına aracılık etmekte ve siyasetin etki alanını genişletmektedir." (Sayımer \& Çetinkaya, 2015, s. 227).

Twitter, haber alma ve haber dağıtım aşamasında da önemli bir rol oynamaktadır. Hem toplumun habere ulaşma aracı olarak işlev görmekte hem de gazetecilerin haber kaynağı ve okuyucuya/takipçiye haber dağıım aracı konumundadır. Teknik mimarisi, zamandan ve mekândan bağımsız bir şekilde etkileşime olanak tanıması gibi özellikleri sayesinde, medya kuruluşları ve gazetecilerin kullanımları açısından önemli bir iletişim alanı olduğu söylenebilir. Büyük bir kullanıc grubuna hitap eden Twitter, günümüzde yüksek etkileşimli bir bilgi ağına dönüşmüştür. "Bu sayede, sadece okuyan ya da izleyen pasif kullanıcıların yerini ileti paylaşan, yorum yapan, haber üreten ya da yayan aktif özneler almış, bu dönüşüm hem medya kuruluşları hem de gazetecilere alternatif haber kaynaklarına, seslere ve fikirlere ulaşma, onlarla iletişime geçme olanağı yaratmıştır." (Çaba, 2019, s. 97).

Twitter'da haberler, geleneksel medya araçlarıyla kıyaslandığında daha hızlı ve sansürsüz bir şekilde yayılma imkânına sahiptir. Twitter bu avantajlarının yanında birtakım dezavantajları da bünyesinde barındıır. Bu dezavantajların başında Twitter'da bilgi akışının hızlı gerçekleşmesi gelmektedir. Bazen Twitter'da yayınlanan içerikleri hızlı akıştan dolayı takip etmek zorlaşabilmektedir. Bu yüzden Facebook'ta olduğu gibi yayınlanan bir içerik hakkında günlerce uzun uzadıya tartışmak daha zordur. Twitter'da "tartışmalar daha çok anlık atışmalar şeklinde gerçekleşir. Bu sebeple Facebook daha statik yapısıyla tartışma ve gruplaşmaya daha uygunken, Twitter sürekli devam eden bilgi ve fikir akışıyla haberciliğe daha yakın bir yapı sergilemektedir" (Tosuner, 2015, s. 135-136). 
Twitter, siyasi söylemlerin yayılımında, ulusal ve küresel gündemlerin oluşmasında önemli bir rol oynadığı için birçok akademik çalışmanın da konusunu oluşturmuştur. Bu yapılan çalışmada olduğu gibi sosyal medya üzerine yapılan araştırmaların büyük bir çoğunluğunun Twitter verileri üzerine odaklanmasının temel nedeni, hem içeriği üreten kaynakların Twitter'ı daha fazla kullanması hem de içeriğin daha kamusal olma özelliği taşımasıdır. (Hülür \& Yaşın, 2019b, s. 10).

\section{TWITTER VE KANAAT ÖNDERLERI}

Günümüzde yaygın bir biçimde kullanılan sosyal paylaşım ağları sayesinde bireyler, kendi kişisel sayfalarını ilgi duydukları alanlara yönelik olarak oluşturabilmekte, geliştirilen uygulamalarla karşııklı etkileşimde bulunabilmekte, kişisel yaşamlarına dair bilgileri ve oluşturdukları içerikleri yakın veya uzak çevresiyle paylaşabilmektedirler (Balcı \& Baloğlu, 2018, s. 209). Başta Facebook, Twitter, Instagram gibi uygulamalar olmak üzere çeşitli sosyal paylaşım ağlarının ortaya çıkması ve bireyler tarafından kullanımının yaygınlaşmasıyla iletişim alanında birçok değişim ve dönüşüm yaşanmıştır. Artık toplumun büyük bir kısmının, haberlere ulaşmak, elde ettiği haberleri çevresine ulaştırmak, yaptığı aktiviteleri paylaşmak, gündemdeki bir konu hakkında fikirlerini açıklamak gibi çeşitli nedenlerle günlük hayattaki yaşamlarının neredeyse tüm alanlarında sosyal ağları kullandıkları görülmektedir. Yüksek etkileşim özelliği, kolay ulaşılabilir olması, kullanım kolaylığı gibi özellikler sosyal ağların toplumda büyük bir kullanıcı grubuna ulaşmasında başat faktör olmuştur.

Sosyal ağlarda bazı kullanııılar, deneyimleri, kavrayışları, karizmatik kişilikleri gibi özellikleri nedeniyle takipçilerinin görüşünü etkileme ve onları belirli konularda yönlendirme yeteneğine sahiptirler. Ayrıca sosyal ağlarda bireyler, yaptıkları paylaşımlar ve diğer kullanıcılarla kurdukları etkileşimler neticesinde kanaat önderleri olarak başkalarının fikirlerini etkileyebildikleri gibi onlardan etkilenme yoluna da gidebilmektedirler (Bamakan, Nurgaliev, \& Qu, 2019, s. 200).

Facebook, Twitter, Instagram gibi sosyal paylaşım ağları, kullanıcıların sadece arkadaşları ve aile bireyleri gibi yakın çevresindeki kişilerle etkileşime geçmelerine olanak tanımakla kalmaz aynı zamanda onların ülke ve dünya gündemine dair çeşitli olay ve olgulardan da haberdar olmalarını sağlar. Bilginin, bu alanları kullanan bireyler arasında hızı bir şekilde yayılması, sosyal ağların temel özelliklerinden biridir (Adalat, Niazi, \& Vasilakos, 2018, s. 2). Sosyal ağlar, yalnızca bilginin tüketildiği alanlar değil aynı zamanda 
içerikte üretildiği alanlardır. Sosyal ağlarda görüntü ve video gibi içerikler oluşturmak, çeşitli platformlarda var olan içerikleri aktarmaktan daha fazla dijital beceri, ilgi ve çaba gerektirir. Sosyal paylaşım ağlarında çok sayıda bilgi kaynağına sahip olabilen kanaat önderleri, sosyal ağlarda içerik üretimi konusunda diğer bireylerle karşılaştırıldığında daha aktif olabilmektedirler (Choi, 2015, s. 701).

Sosyal paylaşım ağları, yönetenlerle yönetilenler arasında doğrudan ve eş zamanlı etkileşim sağlayarak; iktidarın söz ve icraatları hakkında bireylerin fikir, öneri ve eleştirilerini ortaya koymasına fırsat vererek demokratik katılımın gerçekleşmesine imkân vermektedir (Bingöl \& Yanık, 2020, s. 221). Twitter kanaat önderleri ise çeşitli tartışmalar ve fikir alışverişi yoluyla diğer bireyleri siyasi süreçlere katılmaya teşvik etmektedir (Park, 2013, s. 1641). Sosyal ağ siteleri içerisinde Twitter, çeşitli özellikleri itibariyle bireylerin daha geniş ağlara dâhil olmalarına olanak verir. Park, yaptığı araştırmada Twitter'daki kanaat önderlerinin diğer kanaat önderleriyle karşılaştırıldığında daha geniş sosyal ağlara sahip olduğu için geniş halk kitleleri üzerinde de daha fazla etkiye sahip olabileceğini öne sürmüştür. Twitter'da kullanıııların kanaat önderleri olarak algılanması ne kadar yüksek olursa, diğer bireyleri harekete geçirme ve kamuoyunda fikirlerini ifade etme düzeyleri de o kadar yüksek olmaktadır (2013, s. 1646-1647).

Twitter'daki kanaat önderliğini geleneksel kanaat önderliğinden ayıran üç unsur vardır (Park, 2018, s. 10-12):

- Twitter kanaat önderleri, çevrimdışı kanaat önderlerinden daha fazla ve daha çeşitli haber kaynaklarına sahiptirler (Geleneksel medya, haber siteleri, sosyal medya, yurttaş gazeteciler)

- Twitter kanaat önderleri, içeriklerine haber kaynakları ve çeşitli bağlantılar ekleyerek tweetlerini desteklemektedirler.

- Twitter kanaat önderleri, çeşitli haber kaynaklarından aldıkları haberleri kendi yorumlarını da ekleyip özetleyerek takipçileriyle paylaşırlar. Bu çerçevede takipçileri için birer haber yardımcısı görevi üstlendikleri görülmektedir.

Günümüzde çevrimiçi ortamlarda haber hikâyelerine ulaşan bireylerin rolü değişmiştir. Bireyler bu alanlarda haberleri yalnız tüketmekle kalmamakta aynı zamanda haberler üzerine değerlendirme yapan, öğrendiği olay ve olguları araştıran, bunları çeşitli şekillerde yeniden üreten ve paylaşan bir kimliğe bürünmektedirler. Kısacası, bireyler çevrimiçi ortamlarda sadece haber tüketenler değildir. Aynı zamanda erişim sağladıkları haberleri çeşitli şekillerde yeniden dizayn ederek üretenler olarak da faaliyet 
gösterirler (Picone, 2007, s. 104). Park (2018), günümüzde sosyal medya kanaat önderlerinin “News Curation"1 yöntemine yöneldiklerine dikkat çekmektedir. "News Curration, belirli bir hedef için, belirli bir konu veya konuyla ilgili en alakalı hikâyeleri bulma, damıtma, değer katma, koruma ve paylaşma sanatıdır. News Curation, alanında uzmanlık, iletişim becerileri, deneyim ve sezgi gerektiren çok disiplinli, zaman alıc bir faaliyettir." (Good, 2016). "News Curation", diğer sosyal medya kullanım pratiklerinden bir takım farklılıklar arz etmektedir. Bu yöntemi benimseyenler haberleri, "...aktif ve eleştirel bir şekilde değerlendirir, farklı bakış açıları ve bilgiler eklerler." Twitter'da aktif olan kullanıcılar, haberleri takipçileri için daha anlaşııı hale getirmeye yönelik faaliyetlerde bulunurlar (Park, 2018, s. 5). Twitter'da bireyler, çeşitli kaynaklardan elde ettikleri haberleri takipçilerinin daha iyi bir şekilde anlayabilmeleri için kendi yorumlarını ve bakış açılarını da ekleyerek paylaşırlar. Bu şekilde, Twitter kanaat önderlerinin haber içeriklerini bulup birleştirerek ve yeniden dizayn edip yorumlayarak takipçileri arasında etkili oldukları görülmektedir (s. 11-12).

Wu, Hofman, Mason ve Watts (2011), medyaya takipçilerinden daha fazla bağı ve medya içeriklerine daha fazla maruz kalan bireylerin, Twitter'da bilginin dağııılması noktasına önemli bir rol oynadığını tespit etmişlerdir. Ayrıca, Twitter'da yayılan bilgilerin çoğunluğunun kaynağının medya kuruluşları olduğunu görmüşlerdir. Bu çerçevede, sosyal medya ortamlarında da iki aşamalı akış kuramı ve kanaat önderliği kavramının geçerliliği noktasında önemli bir destek sağladıkları söylenebilir (s. 713714).

Sosyal paylaşım ağlarının toplumsal yaşamda önemli bir konuma gelmesiyle birlikte kanaat önderliği kavramı Facebook, Twitter, Instagram gibi ağlarda sorgulanmaya başlamıştır. Nitekim bu çerçevede birçok çalışmanın yapıldığı görülmektedir. Yapılan araştırmaların büyük bir kısmı, internet ve sosyal ağ siteleri gibi gelişen iletişim teknolojileriyle birlikte kanaat önderliği kavramının bu ortamlara taşındığını vurgulamaktadır. Örneğin, "Yeni Medya Çağında Siyasi Konuşma ve Kanaat Önderliği: 24 Haziran Cumhurbaşkanlığı Seçimi Örneğı" ismiyle Türkiye'de yapılan çalışmada, yeni medya ortamlarında kanaat önderleri kavramının geçerliliği sorgulanmıştır. Sonuç olarak kanat önderlerinin, internet ve sosyal ağ siteleri gibi yeni mecralarda da yer aldıkları görülmüştür. "Yeni medyanın etkilenen ve çevrimiçi kanaat önderleri ile aynı kişiler olduğu düşünülen geleneksel anlamda kanaat önderlerinin varlıklarını

\footnotetext{
1 "News Curation", haber iyileştirme süreci olarak ifade edilebilir.
} 
sürdürdükleri, bunlardan başka sosyal medyada haber ve politik bilgileri oldukça aktif olan kanaat önderleri ve görüş arayan kişilerin bulunduğu" tespit edilmiştir (Güz \& Demirtaş, 2019, s. 94).

Buradaki makale konusuyla benzer birtakım çalışmalarında yapıldığı saptanmıştır. Örneğin, Bohórquez-Pereira ve diğerleri (2020), çevrimiçi ortamlarda kadın köşe yazarlarının hangi konular üzerinde durdukları ve kanaat önderleri olarak sınıflandırııp sınıflandırılamayacaklarını incelemişlerdir. Çalışma sonucunda, çevrimiçi ortamlarda köşe yazarlarının bilgilendirici tarzı ve yorumlayıcı tutumlarını korudukları ve sosyal medya ortamlarındaki (Facebook) takipçileriyle gerçekleştirilen etkileşimin, onların kamuoyu liderleri olarak görülmesine olanak sağladığı tespit edilmiştir. Kamuoyu liderleri olarak köşe yazarlarının özellikle Facebook'ta okuyucularıyla/takipçileriyle ve diğer üyelerin birbirleriyle etkileşime geçmesine izin veren topluluklar oluşturması, nihayetinde bu ortamlarda gerçekleşen etkileşimler, onların görüşlerine ilgi gösterildiğini ortaya koymuştur $($ s. 67, 86).

Çaba ve Yeniçeri Alemdar (2018), "...ana akım ve alternatif medyada yer alan gazetecilerin Twitter'da kendilerini nasıl tanıttıklarına ve markalaştıklarına, gazetecilerin Twitter'ı kullanma pratikleri üzerinden sosyal medyanın geleneksel haber odası uygulamalarını nasıl dönüştürdüğüne" dair bir çalışma gerçekleştirmişlerdir (s. 660). Çalışma sonunda ana akım ve alternatif medyadaki gazeteciler kıyaslandığında kişisel tanıtım açısından kayda değer bir fark olmasa da ana akımdaki gazetecilerin Twitter'da daha fazla kişisel tanıtıma odaklandıkları, alternatif medyadaki gazetecilerin ise daha çok haber ve bilgi paylaşımı yaptıkları görülmüştür. "Her iki bulgu-iletişim türü ve işlevi- birlikte değerlendirildiğinde, ana akıma bağı gazetecilerin daha çok kişisel tanıtımları için tweet attıkları ortaya çıkmaktadır" (s. 674). Ayrıca, alternatif medyadaki gazetecilerin Twitter'ı görüş, eleştiri ve yorumlarını açıklama konusunda ana akımdaki gazetecilere oranla daha fazla etkin oldukları görülmüştür (s. 675).

Bu makale konusuyla benzer özellikler taşıyan bir diğer çalışma ise Bakan (2017) tarafından yapılmıştır. Washington Post gazetesi yazarlarının gazete yazıları ve Twitter paylaşımlarına odaklanan araştırmacı, gazetecilerin sosyal medya kullanımlarının meslek pratiklerine etkisini ortaya koymaya çalışmıştır. Gazetecilerin, gazetedeki yazıları ve sosyal medya paylaşımları arasındaki benzerlik ve farklılıklar, bu benzerlik ve farklııkların tematik alanlara göre değişim düzeyi ve buradan hareketle Twitter'ı alternatif bir medya olarak kullanımları ele alınmıştır (s. 263, 272) Çalışma sonunda bazı yazarların (Ed O'Keefe, Philip Rucker ve Robert Barnes) gazetelerde oluşturdukları içerikler ve Twitter 
paylaşımları arasında anlamlı bir benzerlik bulunmazken, bazı yazarların (Carolyn Johnson ve Sari Horwitz) gazetedeki yazıları ve Twitter'da paylaştıkları içeriklerin benzerlik gösterdiği tespit edilmiştir. Ayrıca Washington Post yazarlarından “Philip Rucker, Robert Barnes ve Ed O’Keefe'nin özellikle siyasal, uluslararası politika ve yasal düzenlemelerle ilgili konularda Twitter'ı alternatif bir medya olarak kullandıkları görülmüştür" (s. 263).

Marcos-García ve diğerleri (2020) ise siyasi tartışma programlarına katılan kanaat önderlerinin (uzmanlar, gazeteciler ve medya editörleri) İspanya 2019 Kasım genel seçim dönemindeki Twitter kullanımlarını incelemişlerdir. Çalışma sonunda, televizyonda yayınlanan siyasi talk-showlara katılan kanaat önderlerinin öncelikle haber verme ardından ise analiz ve eleştiri işlevini yerine getirdiklerini tespit etmişlerdir. Ayrıca, bu üç grup arasında Twitter'ı kullanım açısından farklılaşmalar olduğu bulunmuştur. Gazetecilerin daha çok mizah ögeleri ve etkileşim yoluyla Twitter'ı eleştirilerini ifade etmek için kullandığı, medya editörlerinin daha tarafsı ve kendi medya şirketlerinin tanıtımıyla ilgilendiği, uzmanların ise politik haberleri gazetecilerden daha fazla analiz ettikleri ve bilgi verdikleri görülmüştür (s. 277, 289).

Türkiye'de sosyal ağlarda gazetecilik pratikleri ve bu ağlarda gazetecilerin faaliyetlerine odaklanan çalışmaların da olduğu belirlenmiştir. Çaba (2019), Türkiye'deki gazetecilerin Twitter kullanımlarını ve gazetecilik uygulamalarındaki dönüşümü, Twitter'ın sunduğu olanakların gazeteciler tarafından nasıl kullanıldı̆ını incelemiştir. Araştırmada özellikle göze çarpan bulgu; takipçi etkileşimi bağlamında "...gazetecilerin farklı haber kaynaklarından yeni haber ve bilgi bulma, o bilgi ve haberi değerlendirme ve yayma, katılımc bir pratikle haberi dinamik bir süreç içinde geliştirme..." sürecinde düşük bir yoğunluğa sahip olduklarının tespit edilmiş olmasıdır. Ayrıca örneklem olarak ele alınan gazetecilerin, son kullanıcı gazeteciliğine yönelik eğilimlerde düşük seviyede oldukları görülmüştür (s. 115-117).

Gelişen iletişim teknolojileri ve değişen toplumsal yapılarla birlikte bireylerin iletişim alışkanlıkları da değişmiştir. İki aşamalı akış kuramının ortaya çıktığı dönem ve günümüzdeki iletişim yapısı karşılaştırılı̆̆ında, kanaat önderliği kavramının farklı bir aşamaya geçtiğine vurgu yapan çeşitli araştırmacılarda vardır. Örneğin Bennet ve Manheim (2006, s. 214), gelişen iletişim teknolojileri ve toplumun iletişim alışkanlıklarında yaşanan değişimlerle, bireylerin bilgi alma ve bu bilgiyi işleme sürecinin de değiştiğine vurgu yapmaktadır. Bu çerçevede araştırmacılar, gelişen teknolojiler ve bununla 
birlikte toplumun iletişim alışkanlıklarında yaşanan değişimlerle birlikte kanaat önderliği kavramının önemini yitirdiğini ve iki aşamalı akış kuramının geçerliliğinin tartışılabileceğini öne sürmüşlerdir.

\section{KANAAT ÖNDERLERI OLARAK KÖŞE YAZARLARI}

Gazetecilik en genel tanımıyla, bireylerin sorunlarının çözümlenmesine yardımcı olacak bilgilerin toplanması ve ulaştırılması sürecidir. Gazetecilik işlemi ise, haber için gereken enformasyonun toplanmasını, düzenlenmesini, yazıımasını ve dağııılmasını içerir. Gazetecilik faaliyetlerinde dikkat edilmesi gereken temel unsurlardan biri haber ile yorumun birbirine karıştırılmamasıdır. "Haber, gerçeklere ve verilere dayalı bilgilendirmedir. Buna karşılık, yorum ise yazarın, yayımlayanın veya yayın şirketlerinin düşüncelerini, inançlarını, kişisel yargılarını içerir. Haber yayını, gerçeklere dayandırılmalı ve doğruluğu kanıtlanır olmalıdır." (Tokgöz, 2015, s. 124). Haberleri, gerçeklere ve verilere dayanarak birebir aktaran gazetecilerle birlikte gündemdeki haberler, çeşitli olaylar ve olgular hakkında yorum yapan, çeşitli değerlendirmelerde bulunan köşe yazarları da toplum için vazgeçilmez unsurlardan biridir.

"Köşe yazarlığı için toplumsal etki gücüne sahip, simgesel erk sahibi olan, kimi zaman yargı mekanizması olarak, kimi zaman siyasi ve toplumsal krizlerde bir başvuru mercii olarak işleyen bir müessese diyebiliriz." (Altınoklu Şenay, 2016, s. 120). Medyanın önemli bir alt alanı olarak köşe yazarlığıı gazetelerde fiziksel olarak önemli bir yere sahiptir. Köşe yazarlarından beklenen, oluşturdukları içeriklerle "... haber metinleriyle yapılamayanı yaparak, olayı farklı açılardan yorumlayıp okura sunmalarıdır" (Dursun, 2015, s. 2). Gündelik hayatı çeşitli yönleriyle ele alan; politika ve ekonomik konular başta olmak üzere çeşitli olay ve olgulara dair fikir beyanında bulunan köşe yazarları, gazetelerde köşe yazmanın yanı sıra çeşitli televizyonlarda ve radyolarda program sunarak veya bu programlara katılıp yorum yaparak da kamuoyunun oluşumuna katkı sağlamaktadırlar (Özkır, 2016, s. 39).

Köşe yazarları, "...siyasal konuları detaylandırmak, kamuoyunun gözden kaçırdığı detayları işlemek, siyasal aktörlerin projeleri ve partilerin politikaları hakkında topluma doğru bilgileri aktarmak ... " gibi misyonları yerine getirmektedirler (Gölcü \& Yüksel, 2018, s. 771). Ayrıca, kamuoyunun doğru bilgilendirilmesi, demokrasinin ilerlemesi, tartışma kültürünün ve çok sesliliğin geliştirilmesi konularında da basına ve özellikle bir gazetecilik alanı olarak köşe yazarlarına önemli görevler düşmektedir (s. 790). Köşe yazarları bu görevleri yerine getirirken adil, elindeki gücü bir imtiyaz olarak değil topluma hizmet 
olarak gören, topluma hizmet gayesi içerisinde olan, eleştirel düşünen iyi bir gözlemci olmalıdırlar (Tekinalp, 2008, s. 121-122). Bilgilendirme, kamuoyu oluşturma ve toplumsallaştırma gibi çeşitli işlevleri yerine getiren köşe yazarları, bulundukları konum itibariyle kitle iletişim araçlarına ve haber kaynaklarına daha fazla maruz kalan donanımlı kişilerdir. Bu çerçevede toplumdaki olay ve olguları diğer bireylerden farkıı bir biçimde yorumlayabilen köşe yazarları, toplumun kanaat önderleri olarak önemli bir misyonu yerine getirirler.

Köşe yazarları, kanaat önderleri olarak kabul edilir ve en önemli işlevlerinden biri oluşturdukları metinler aracılı̆ııla eleştirel düşüncenin gelişmesini sağlamaktır. Onların kanaat önderleri olarak görülmesini sağlayan en önemli özelliklerinden biri; oluşturdukları içerikler ve yaptıkları yayınlar konusunda, okuyucularının/takipçilerinin sahip olduğu görüş ve fikirleri sansürlememeleridir (Bohórquez-Pereira ve diğerleri, 2020, s. 85). Gazetecilik faaliyetlerinin bir alanı olarak köşe yazarlarından beklenen gündemdeki olay ve olgular veya bireyler için önemli olarak görünen çeşitli haberler ve konular hakkında görüş, düşünce ve yorumlarını okuyucularına/izleyicilerine/takipçilerine aktarmalarıdır. Böylelikle gazeteciler, yaptıkları yorumlar, ifade ettikleri görüş ve düşünceleriyle bireylerin kanaatlerinin şekillenmesinde önemli bir rol oynamaktadırlar.

Gelişen iletişim teknolojileriyle birlikte köşe yazarları, internet gazetelerinde veya sosyal medya hesaplarında çeşitli konulardaki düşüncelerini, köşe yazılarını veya spot ifadeleri paylaşarak, geleneksel medyanın yanında bu platformlarda da geniş çaplı okuyucuya/takipçiye ulaşabilmektedir. Bu noktada "köşe yazarlarının kendi fikirlerini paylaştığı mecranın çeşitlenmesi; medyanın yoruma dayalı yönünü ön plana çıkartmış ve medyanın siyaset, ekonomi, eğitim ve dış politika gibi diğer alanlarla kurduğu ilişkilerde köşe yazarlarının kanaatleri önem kazanmıştır" (Özkır, 2016, s. 39). Özellikle köşe yazarları, sosyal ağlarda paylaştıkları içerikler itibariyle farklı konularda duygu ve düşüncelerini çok daha geniş halk kitlelerine ulaştırma imkânına sahip olmuşlardır. Ayrıca, sosyal paylaşım ağlarında gazetecilerin paylaştıkları içeriklere okuyucuların/takipçilerin/izleyicilerin olumlu veya olumsuz yorumlar yaparak yüksek etkileşimli bir ortamda fikirlerini ifade edebilmeleri, okuyucuların/takipçilerin/izleyicilerin kanaatlerinin şekillenmesini de daha fazla etkileyebilmektedir.

Illetişim teknolojilerinde yaşanan değişimler gazetecilik alanında önemli değişiklikler meydana getirmiştir. Yeni medya, bireylerin gündelik yaşamlarında faydalandıkları önemli bir mecra haline 
gelmiştir. Bu durum, geleneksel medyanın yeni medyaya uyum sağlama gerekliliğini doğurmuş ve bu çerçevede adımlar atılmıştır (Güz, Yegen, \& Yanık, 2016, s. 299). Yeni iletişim teknolojileri içerisinde Facebook, Twitter ve Instagram gibi sosyal paylaşım ağları ise gazeteciliğin doğasında yeni gelişmeler ortaya çıkaran önemli bir alan olmuştur. Sosyal paylaşım ağları, köşe yazarlığı olgusunda da yeni bir düzlem ortaya çıkarmıştır. Köşe yazarlarının sosyal paylaşım ağlarında kısa, çarpıcı ve slogana dönüşmüş̧ içerikler paylaşmaları, hem yazma hem de okuma pratiğini dönüşüme uğratmıştır. Köşe yazarları artık bu trende uyum sağlamak adına, yazılarının tamamı yerine, içinden seçtikleri pasajları slogan haline getirerek sosyal ağlarda paylaşmaya başlamışlardır. Bu durum, gazetecilikteki geleneksel bazı kalıpların yeni iletişim teknolojileriyle birlikte dönüşüme uğradığını ve gazeteciliğin bu teknolojilerin doğasına uygun bir şekilde pozisyon aldığını göstermektedir. Ayrıca, köşe yazarlarının geleneksel olarak gazetelerde köşe yazmakla birlikte artık yazılarından bazı noktaları sosyal ağlarda paylaşmaları etkilerini de genişletebilmelerini sağlamış ve böylece kamusal aktörlere dönüşebilmelerinin önünü açmıştır (Özkır, 2016, s. 50-51). Bu anlatılanlar noktasında, köşe yazarlarının sosyal ağları nasıl ve ne şekilde kullandıklarının tespit edilmesi önem arz etmektedir. Çünkü, kanaat önderleri olarak köşe yazarlarının toplumun kanaatlerinin şekillenmesinde önemli bir etkiye sahip olduğu göz önüne alındığında, özellikle Twitter başta olmak üzere çeşitli sosyal paylaşım ağlarının, köşe yazarlığı faaliyetinde bulunan kişiler için nasıl bir işleve sahip olduğunun ortaya konması gerekmektedir.

\section{YÖNTEM}

Türkiye'de yeni iletişim teknolojileri, sosyal medya ve kanaat önderleri arasındaki ilişkiye odaklanan az sayıda çalışma vardır. Kanaat önderleri üzerine yapılan çalışmaların çoğunluğunun sosyal medya fenomenleri üzerine olduğu görülmektedir. Toplumun kanaat önderleri olarak köşe yazarlarının Twitter kullanımlarının incelenmesi, önemli bir konuya ışık tutacaktır. Bu çerçevede araştırmanın temel amacı, Türkiye'de köşe yazarlarının Twitter kullanım pratiklerini inceleyerek kanaat önderleri olarak Twitter'ı nasıl ve ne şekilde kullandıklarını saptamaktır. Çalışmanın araştırma soruları 4 başlık altında toplanmıştır:

1. Köşe yazarlarının, Twitter'da oluşturdukları içeriklerin ne kadarı link paylaşımı, ne kadarı retweet, ne kadarı tweet alıntılama ve ne kadarı Twitter'a özgü (yazarların kendi sesinden ürettikleri) içeriklerdir? 
2. Köşe yazarları, tweet alıntılama ve link paylaşımlarını nasıl ve ne şekilde kullanmaktadırlar?

3. Türkiye'de kanaat önderleri olarak köşe yazarlarının, Twitter'daki temel işlevleri nelerdir?

4. Türkiye'de kanaat önderleri olarak köşe yazarlarının, Twitter'da bahsettikleri temel konular nelerdir?

Araştırmada, amaçlı örnekleme yöntemlerinden biri olan tipik durum örneklemesi kullanılmıştır. Basılı gazetelerde köşe yazarlığı faaliyetinde bulunan kişiler arasından 5 köşe yazarı, tipik durum örnekleme yöntemi kullanılarak seçilmiştir. "Amaçı̈ı örneklemde önceden tanımlanarak belirlenmiş amaca uygun birimler inceleme için seçilir" (Erdoğan, 2012, s. 210). Amaçlı örneklem yöntemlerinden biri olan tipik durum örneklemesi ise "... araştırma problemi olarak evrende yer alan çok sayıdaki durumdan tipik olan bir durumun belirlenerek bu örnek üzerinden bilgi toplanmasını gerektirir." Burada temel olan sıra dışı özellik göstermeyen, normal ve tipik durumların örneklem olarak seçilmesidir (Büyüköztürk, Kılıç Çakmak, Akgün, Karadeniz, \& Demirel, 2020, s. 94).

Araştırma, 01 Aralık 2020-31 Ocak 2021 tarihleri arasında örneklem olarak seçilen 5 köşe yazarının Twitter verilerine odaklanmaktadır. Köşe yazarlarının iki aylık süreç içerisinde yaptığı paylaşımlar niceliksel içerik analizi ile değerlendirilmiştir. içerik analiziyle birlikte mesajların bazı özellikler konusunda sistematik ve objektif bir şekilde çıkarımlar yapılabilir. Sosyal bilimlerde sıklıkla kullanılan tekniklerden biri olan içerik analizi, belirli kurallar çerçevesinde yapılan "...kodlamalarla bir metnin bazı sözcüklerinin daha küçük içerik kategorileri ile özetlendiği sistematik, yinelenebilir bir teknik olarak tanımlanır." (Büyüköztürk ve diğerleri, 2020, s. 259). İçerik analizi yoluyla veriler belirlenir ve verilerin içinde saklı olan yapılar ortaya çıkarılmaya çalışıır. "içerik analizinde temelde yapılan işlem, birbirine benzeyen verileri belirli kavramlar ve temalar çerçevesinde bir araya getirmek, bunları okuyucunun anlayabileceği bir biçimde düzenleyerek yorumlamaktır." (Yıldırım \& Şimşek, 2018, s. 242). Bu analiz tekniğiyle çeşitli görüntüler, yazılı veya sözlü metinler analiz edilerek rakamlara dönüştürülür ve daha sonra bu rakamlar üzerinden yorumlamalar yapııır (Şahin, 2017, s. 191). 
Köşe yazarlarının Twitter paylaşımları içerik analizine tabi tutulurken, Noguera Vivo'nın (2013, s. 105-109) geliştirdiği kodlama şeması ${ }^{2}$ ile Marcos-García ve diğerlerinin (2020, s. 281-283) siyasi tartışma programlarına katılan kanaat önderlerinin Twitter kullanımlarını tespit etmek için oluşturdukları kategoriler (Tablo 1 ve Tablo 2) kullanılmıştır. ${ }^{3}$ Araştırma verileri ise SPSS 22 programı kullanılarak analiz edilmiş, sonuçlar frekans analizi ve yüzde dağılımı ile değerlendirilmiştir.

Tablo 1 İşlev Çalışması İçin Analiz Kategorileri (Marcos-García ve diğerleri, 2020, s. 282)

\begin{tabular}{|c|c|c|}
\hline \multicolumn{2}{|c|}{ FONKSIYON } & TANIMLAMA/AÇIKLAMA \\
\hline Bilgi & Bilgi vermek & $\begin{array}{l}\text { Ana işlevi tarafsız bir şekilde bilgilendirmek olan } \\
\text { tweetler, konuyu belirtmek, bazı verileri vurgulamak } \\
\text { veya bir içeriği, yazıyı aktarmak. }\end{array}$ \\
\hline \multirow{3}{*}{ Görüş/Fikir/Kanaat } & Eleştiri & $\begin{array}{l}\text { Ana işlevi bir veya daha fazla aktörü (politikacılar, } \\
\text { gazeteciler, girişimciler vb.), ideolojileri, çeşitli } \\
\text { faaliyetleri, belirli olayları veya argümanları } \\
\text { eleştirmek. }\end{array}$ \\
\hline & Başkaları için destek & $\begin{array}{l}\text { Politikacılar, gazeteciler, girişimciler gibi aktörlerin } \\
\text { eylemlerini, ideolojilerini, belirli olayları veya } \\
\text { argümanları savunan, yeniden onaylayan, doğrulayan } \\
\text { tweetler. }\end{array}$ \\
\hline & $\begin{array}{l}\text { Saldırı karşısında } \\
\text { kendini savunma }\end{array}$ & $\begin{array}{l}\text { Başka kullanıııların eleştirisi veya saldırısı durumunda } \\
\text { kanaat önderlerinin kendilerini savunduğu tweetler. }\end{array}$ \\
\hline Yorumlama & Analiz & $\begin{array}{l}\text { Diğer aktörlerin girişimleri, görüşleri veya olaylar } \\
\text { üzerine lehte veya aleyhte olmayan düşünceler içeren } \\
\text { tweetler. Herhangi bir olayın nedenlerini veya } \\
\text { sonuçlarını yansıtan mesajlar. }\end{array}$ \\
\hline \multirow{3}{*}{ Topluluk } & Takdir & $\begin{array}{l}\text { Başkalarının yorumlarını, eylemlerini veya girişimlerini } \\
\text { takdir eden tweetler. }\end{array}$ \\
\hline & Kullanıcılarla etkileşim & $\begin{array}{l}\text { Diğer kullanıcıların cevaplaması ve yorum yapması için } \\
\text { sorular soran tweetler. }\end{array}$ \\
\hline & Kişisel bilgi & $\begin{array}{l}\text { Kişisel zevkler, boş zaman etkinlikleri, aile veya } \\
\text { arkadaş çevresiyle ilgili (daha samimi ve kişisel }\end{array}$ \\
\hline
\end{tabular}

${ }^{2}$ Reply ve mention oranları, link paylaşımı, iç link (kendi medyası), dış link (farklı medya kuruluşları), profesyonel medya kuruluşlarına link, profesyonel olmayan medya kuruluşlarına link, özgün içerik (kendi sesi), retweet oranı, yorum ile retweet, yorum içermeyen retweet, pozitif retweet, negatif retweet gibi başlıklara sahip kodlama şeması.

${ }^{3}$ Noguera Vivo'nın (2013, s. 107-109) kodlama şeması ile Marcos-García ve diğerlerinin (2020, s. 281-283) geliştirdiği kategoriler bu araştırmada temel referans olarak kullanıımıştır. Ancak, gerek çalışmanın amacı, konusu ve örneklemi gerekse ülkelerin toplumsal koşullarındaki farklııklar göz önüne alındığında bir takım eklemeler yapılması, bazı noktaların çıkarılması ve yeni kategoriler eklenmesi gibi değişiklikler söz konusu olmuştur. 


\begin{tabular}{|c|c|l|}
\hline \multirow{2}{*}{ Markalaşma } & Mizah & $\begin{array}{l}\text { davranışlar) bilgiler veya görüntüler gibi özel hayata } \\
\text { dair tweetler. }\end{array}$ \\
\cline { 2 - 3 } & Profesyonel gündem & $\begin{array}{l}\text { Mesleki programlara dair (konferanslar, televizyon } \\
\text { programları gibi çeşitli etkinlikler) bilgilerin paylaşıldı̆̆ı } \\
\text { tweetler. }\end{array}$ \\
\cline { 2 - 3 } & Kendini tanıtma & $\begin{array}{l}\text { Kariyerleri ile ilgili yönleri teşvik eden tweetler } \\
\text { (örneğin bir röportaj yapmışlarsa veya bir haber, bir } \\
\text { kitap ya da rapor yayınlamışlarsa). }\end{array}$ \\
\hline Diğerleri & Diğerleri & $\begin{array}{l}\text { Yukarıdaki kategorilerden herhangi birine dâhil } \\
\text { olmayan tweetler. }\end{array}$ \\
\hline
\end{tabular}

Tablo 2 Tweet konularının analizi için kullanılan kategoriler (Marcos-García ve diğerleri, 2020, s. 283)

\begin{tabular}{|l|l|}
\hline KONU & TANıM/AÇıKLAMA \\
\hline Ekonomi & $\begin{array}{l}\text { İstihdam, işsizlik, maaşlar, bütçe açı̆ıı, kamu harcamaları, borçlar, kriz, } \\
\text { vergiler, girişimcilik ve sözleşmelerle ilgili tweetler. }\end{array}$ \\
\hline Sağıık & Toplum sağlığını ilgilendiren konulardaki tweetler. \\
\hline Eğitim & Eğitimsel faaliyetlerle ilgili tweetler. \\
\hline Politika & $\begin{array}{l}\text { Siyasi içerikli konular, devlet yönetimi, politikacılar arasındaki tartışmalar, } \\
\text { meclis oturumları, siyasilerin söylemleri veya eylemleri gibi konulara dair } \\
\text { tweetler. }\end{array}$ \\
\hline Kültürel faaliyetler & Sinema, edebiyat, sanat gibi kültürel faaliyetlerle ilgili twettler. \\
\hline Covid-19 aşı çalışmaları & COVID-19 aşı çalışmalarına dair çeşitli tweetler. \\
\hline Çevre & Kirlilik, bitki örtüsü, fauna ve iklim değişikliği hakkındaki tweetler. \\
\hline Altyapı hizmetleri & $\begin{array}{l}\text { Demiryolları, havaalanları, karayolları gibi ulaşım ve altyapı hizmetleri } \\
\text { hakkındaki tweetler. }\end{array}$ \\
\hline Yolsuzluk & Geniş anlamda siyasi yolsuzlukla ilgili tweetler. \\
\hline Demokrasi ve Özgürlükler & $\begin{array}{l}\text { İnsan hakları, katılım, eşitlik, politik süreçlerdeki değişiklikler ve özgürlükler } \\
\text { gibi demokratik yönlere, yeniliklere odaklanan tweetler. }\end{array}$ \\
\hline Terör & Terörizmle ilgili tweetler. \\
\hline Kişisel konular & Kişisel hayatlarla ilgili tweetler. \\
\hline Dışişleri & Avrupa, Amerika ve dünyanın diğer bölgelerine dair tweetler. \\
\hline Göçmenlik & Ulusal ve uluslararası göç (mülteciler) hakkındaki tweetler. \\
\hline Savunma ve adalet & $\begin{array}{l}\text { Silahlı kuvvetler, askeri harcamalar, ulusal güvenlik, adli süreçler, } \\
\text { hapishane ve cezalarlar ilgili tweetler. }\end{array}$ \\
\hline Medya & $\begin{array}{l}\text { Medya çalışanlarına, kitle iletişim araçlarındaki çeşitli programlara, } \\
\text { medyanın çalışma şekline ve konumuna odaklanan tweetler. }\end{array}$ \\
\hline Oylama ve seçim & Oylama, seçim anketleri ve erken seçim tartışmalarına odaklanan tweetler. \\
\hline Spor & Spor faaliyetlerine dair tweetler. \\
\hline Din & Dini konulardaki tweetler. \\
\hline Bilim ve teknoloji & Çeşitli bilimsel faaliyetler ve teknolojik gelişmelerle ilgili tweetler. \\
\hline & \\
\hline
\end{tabular}




\begin{tabular}{|l|l|}
\hline Tanıtım & $\begin{array}{l}\text { Bazı firmalar, ürünler ve medya kuruluşlarının tanıtımı da dâhil reklam } \\
\text { içeren tweetler. }\end{array}$ \\
\hline Konu yok & $\begin{array}{l}\text { Kısa ifadelerden veya birkaç kelimeden oluşan, belirli bir konuya karşısık } \\
\text { gelmeyen ve hangi konu hakkında konuşulduğu anlaşılmayan tweetler. } \\
\text { Kısa nezaket ifadeleri (Örnek: Günaydın, iyi geceler, teşekkür ederim, } \\
\text { başsağlığı dilerim) }\end{array}$ \\
\hline Diğerleri & Bu kategorilerden birinde sınıflandıılamayanlar. \\
\hline
\end{tabular}

\section{BULGULAR}

Iki aylık süreçte örneklem olarak seçilen 5 köşe yazarının paylaştığı 759 tweet analiz edilmiştir. Toplam tweetler içerisinde mention oranı yüzde 5,9 iken reply oranının ise yüzde 0,4 olduğu görülmüştür. Bu noktada köşe yazarlarının Twitter'da, diğer kullanıcılara cevap verme (reply) ve kullanıcıların isminden bahsetme (mention) konusunda etkin olmadıkları anlaşılmaktadır. Analizde, köşe yazarlarının Twitter'da kendi oluşturdukları içerikleri paylaşma oranlarının, yaptıkları paylaşımların yaklaşık üçte birlik bir kısmını oluşturduğu tespit edilmiştir. Yazarların Twitter'a özgü içerik oluşturma oranı yüzde 31,5 (n=239) ile birinci sıradayken, ikinci sırada yüzde 28,6 (n=217) ile farklı çevrimiçi ortamlara link verme üçüncü sırada yüzde 26,2 ( $n=199$ ) ile doğrudan retweet ve son sırada yüzde 13,7 ( $n=104)$ ile tweet alıntılama yer almıştır.

Tablo 3 Tweet, Retweet ve Link Dağıımları

\begin{tabular}{lcc}
\hline & $\begin{array}{c}\text { FREKANS } \\
\text { (f) }\end{array}$ & $\begin{array}{c}\text { YÜZDE } \\
\text { (\%) }\end{array}$ \\
\hline Özgün içerik (Yazarın kendi oluşturduğu içerik) & 239 & $\% 31,5$ \\
Retweet (Yorum eklemeden) & 199 & $\% 26,2$ \\
Tweet alıntılama (Yorum ile birlikte retweet) & 104 & $\% 13,7$ \\
Farklı çevrimiçi ortamlara link (Bağlantı paylaşımı) & 217 & $\% 28,6$ \\
\hline TOPLAM & $\mathbf{7 5 9}$ & $\% 100$ \\
\hline
\end{tabular}

Tweet alıntılama, Twitter'da kullanıcıların oluşturdukları içerikleri çeşitli şekillerde yorumlayarak retweet etmeye verilen isimdir. Köşe yazarlarının, tweet alıntılama yöntemini daha çok pozitif yorumlar yaparak kullandıkları (\%55,9 / n=57) görülmüştür. Tweet alıntılamada negatif yorum oranı ise yüzde 40,2'dir ( $n=41$ ). Yüzde 3,9'luk (n=4) bir kısım da nötr yorum kategorisinde yer almıştır.

Yapılan analiz sonucunda köşe yazarlarının Twitter'da paylaştıkları içeriklerin yaklaşık dörtte birinden fazlasının (\%28,6/n=217) link paylaşımı olduğu tespit edilmiştir. Bu link paylaşımlarının yüzde 
88'lik (n=191) kısmında ise yazarlar, kendi köşe yazılarına bağlantı vermişlerdir. Yüksek düzeyde olmasa da yazarların, köşe yazıları haricinde kendi medyasına ( \%3,7 / $n=8$ ) ve farklı basın-yayın kuruluşlarına da $(\%, 5 / n=14)$ çeşitli haber, bilgi ve yorumlar için link verdikleri görülmüştür. Analiz sonuçlarında dikkat çekici nokta ise yazarların Twitter'da yaptıkları link paylaşımlarının neredeyse tamamına yakınında $(\% 95,7$ / n=202) paylaştıkları bağlantılara kısa spot ifadeler ve yorumlar eklediklerinin tespit edilmiş olmasıdır. Yazarlar, yaptıkları link paylaşımlarının sadece yüzde 4,3'lük (n=99) bir kısmına herhangi bir yorum veya kısa ifadeler eklememişlerdir.

Tablo 4 Link Paylaşımlarına Yorum ve Ifade Ekleme Durumu

\begin{tabular}{lcc}
\hline & $\begin{array}{c}\text { FREKANS } \\
\text { (f) }\end{array}$ & $\begin{array}{c}\text { YÜZDE } \\
\text { (\%) }\end{array}$ \\
\hline Doğrudan/Yorum ve ifade eklemeden link paylaşımı & 9 & $\% 4,3$ \\
Kısa yorumlar ve spot ifadeler ekleyerek link paylaşımı & 202 & $\% 95,7$ \\
\hline TOPLAM & $\mathbf{2 1 1}$ & $\% 100$ \\
\hline
\end{tabular}

Tablo 5'de görüldüğü üzere köşe yazarların çeşitli haber, bilgi ve yorum için yaptıkları retweetlerin kaynağı yüzde 66,8 oranla ( $n=133$ ) Twitter'daki kişisel hesaplardır. Retweet kaynağı açısından ikinci sırada yüzde $16,6^{\prime}$ lık ( $\mathrm{n}=33$ ) oranla kendi kurumu dışındaki medya kuruluşları gelmektedir. Bunu yüzde 10,1 (n=20) ile kendi medyası, yüzde 6,5 ile (n=13) Twitter'da kurumsal olarak faaliyet gösteren çeşitli bilgi ve haber kaynakları takip etmiştir.

Analiz sonuçlarına göre haber, bilgi ve yorum kaynağı açısından Tweet alıntılamada da, retweet dağılımındakine benzer sıralamalar ortaya çıkmıştır. Tweet alıntılama yapan köşe yazarları, yüzde 55,8'lik oranla en fazla Twitter'daki çeşitli kişisel profillerden içerikler kullanmışlardır. Tweet alıntılamada ikinci sırada, yüzde 31,7 ile ( $n=33$ ) kendi kurumu dışındaki profesyonel medyanın Twitter profillerinden alınan haber, bilgi veya çeşitli yorumlar gelmektedir. Tablo 5'de görüldüğü üzere yazarların tweet alıntılamada üçüncü sıradaki kaynakları yüzde 7,7 (n=8) ile kendi medyasıyken bunu yüzde 4,8 ile (n=5) ile Twitter'daki çeşitli kurumsal hesaplar izlemiştir. 
Tablo 5 Link ve Retweetlerde içerik Dağılımı (Link ve Retweet Kaynağı)

\begin{tabular}{|c|c|c|c|c|c|c|c|c|}
\hline & \multicolumn{2}{|c|}{$\begin{array}{l}\text { RETWEET } \\
\text { (YORUM } \\
\text { OLMADAN) }\end{array}$} & \multicolumn{2}{|c|}{$\begin{array}{c}\text { TWEET } \\
\text { ALINTILAMA } \\
\text { (YORUM ILE } \\
\text { BiRLiKTE } \\
\text { RETWEET) }\end{array}$} & \multicolumn{2}{|c|}{$\begin{array}{c}\text { LINNK } \\
\text { PAYLAŞIMI }\end{array}$} & \multicolumn{2}{|c|}{ TOPLAM } \\
\hline & $f$ & $\%$ & $\mathbf{F}$ & $\%$ & f & $\%$ & $f$ & $\%$ \\
\hline Kendi köşe yazısına link & 0 & $\% 0$ & 0 & $\% 0$ & 191 & $\% 88$ & 191 & $\% 36,7$ \\
\hline $\begin{array}{l}\text { Kendi medyasından haber, } \\
\text { bilgi ve yorum }\end{array}$ & 20 & $\% 10,1$ & 8 & $\% 7,7$ & 8 & $\% 3,7$ & 36 & $\% 6,9$ \\
\hline $\begin{array}{l}\text { Kendi kurumu dışındaki } \\
\text { profesyonel medyadan } \\
\text { haber, bilgi ve yorum }\end{array}$ & 33 & $\% 16,6$ & 33 & $\% 31,7$ & 14 & $\% 6,5$ & 80 & $\% 15,4$ \\
\hline $\begin{array}{l}\text { Çeşitli kurumsal web } \\
\text { siteleri veya sosyal } \\
\text { ağlardan haber, bilgi ve } \\
\text { yorum }\end{array}$ & 13 & $\% 6,5$ & 5 & $\% 4,8$ & 3 & $\% 1,4$ & 21 & $\% 4$ \\
\hline $\begin{array}{l}\text { Sosyal ağlardaki kişisel } \\
\text { hesaplardan haber, bilgi ve } \\
\text { yorum }\end{array}$ & 133 & $\% 66,8$ & 58 & $\% 55,8$ & 1 & $\% 0,5$ & 192 & $\% 36,9$ \\
\hline TOPLAM & 199 & $\% 100$ & 104 & $\% 100$ & 217 & $\% 100$ & 520 & $\% 100$ \\
\hline
\end{tabular}

Türkiye'de kanaat önderleri olarak köşe yazarlarının, Twitter'daki temel işlevlerini ortaya koyan veriler göstermektedir ki köşe yazarları, Twitter'ı en çok eleştiri işlevi çerçevesinde kullanmaktadır. Twitter'da yazarlar tarafından paylaşılan içeriklerin yaklaşı üçte birlik bir kısmı (\% 33,1/n=122) çeşitli olay ve olgulara dair eleştiri içermektedir. Tablo 6'da görüldüğü üzere eleştiri işlevinden sonra ikinci sırada yüzde 20,3 ile ( $n=75)$ bilgi verme işlevi yer almıştır. Bu noktada yazarların takipçilerini çeşitli konularda tarafsız bir şekilde bilgilendirme çerçevesinde de yoğun olarak kullandıkları görülmüştür. Analiz işlevi ise eleştiri ve bilgilendirmeden sonra Twitter'da yazarların en sık başvurduğu fonksiyon olarak yer almıştır. Köşe yazarları, Twitter'daki faaliyetlerinin yüzde $13^{\prime} \mid u ̈ k ~(n=48)$ bir bölümünde çeşitli olay ve olgular ile bazı aktörlerin görüş ve düşüncelerine dair lehte veya aleyhte olmayan analizlerde bulunmuşlardır. Köşe yazarlarının Twitter'da çeşitli aktörlerin eylemleri, görüşleri, düşünceleri ve ideolojilerine dair destek mesajları paylaşma oranı ise yüzde 7.3'tür ( $n=27)$. Bu çerçevede yazarların Twitter'ı sadece kendi duygu, düşünce ve ifadelerini paylaşma alanı değil aynı zamanda kanaat önderleri olarak başkalarının duygu ve düşüncelerine destek sağlamak amacıyla da kullandıkları saptanmıştır. Yazarların, çeşitli televizyon programları ve konferanslar gibi profesyonel gündemlerine dair içerik paylaşma oranı ise yüzde 7'dir 


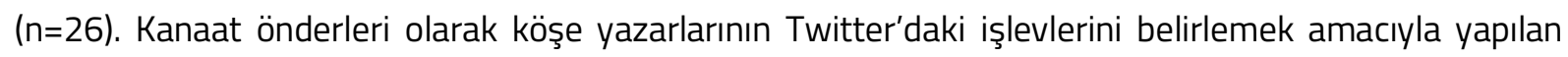
analizde yukarıda işlevler dışında yüzde $4,3(n=16)$ oranında başkalarının eylemlerini ve düşüncelerini takdir eden tweetler ile yine aynı oranda kendi özel yaşamlarına dair kişisel bilgi içeren tweetler paylaştıkları görülmüştür. Kullanıııların yorum yapması ve cevaplaması için soru soran ve bu çerçevede kullanıcılarla etkileşim içeren tweetler yüzde 4,1 (n=15), mizah ögeleri içeren tweetler yüzde 3,6 (n=13), diğer Twitter kullanıcıların saldırıları karşısında yazarların kendilerini savunduğu tweetler yüzde 1,4 (n=5) ve işlev çalışmasında bu kategorilerden herhangi biri içerisine dâhil edilemeyen tweetler ise yüzde 1,6 $(n=6)$ oranındadır.

Tablo 6 Köşe Yazarları Tarafından Paylaşılan Tweetlerin Işlevi ${ }^{4}$

\begin{tabular}{lcc}
\hline & $\begin{array}{c}\text { FREKANS } \\
\text { (f) }\end{array}$ & $\begin{array}{c}\text { YÜZDE } \\
\text { (\%) }\end{array}$ \\
\hline Bilgi vermek & 75 & $\% 20,3$ \\
Eleştiri & 122 & $\% 33,1$ \\
Başkaları için destek & 27 & $\% 7,3$ \\
Saldırı karşısında kendini savunma & 5 & $\% 1,4$ \\
Analiz & 48 & $\% 13$ \\
Takdir & 16 & $\% 4,3$ \\
Kullanıcılarla etkileşim & 15 & $\% 4,1$ \\
Kişisel bilgi & 16 & $\% 4,3$ \\
Mizah & 13 & $\% 3,6$ \\
Profesyonel gündem & 26 & $\% 7$ \\
Kendini tanıtma & 0 & $\% 0$ \\
Diğerleri & 6 & $\% 1,6$ \\
\hline TOPLAM & 369 & $\% 100$ \\
\hline
\end{tabular}

Son olarak çalışmada, köşe yazarlarının Twitter'da bahsettikleri temel konuların neler olduğu analiz edildiğinde Tablo 7'deki sonuçlar ortaya çıkmıştır. Araştırma sonuçları, kanaat önderleri olarak köşe yazarlarının Twitter'da, tahmin edilebileceği üzere en fazla politik konularda içerik paylaştıklarını göstermektedir. Yazarların paylaştıkları içeriklerin yüzde 16'sını ( $n=59)$ politik konulardaki mesajlar oluşturmaktadır. Konu dağıımında yüzde 14,1 (n=52) ile dışişleri kategorisinin ikinci sırda gelmesi, köşe yazarlarının Twitter'da oluşturdukları içeriklerde ülke gündemi dışında uluslararası alana da ağırlık

\footnotetext{
4 Yazarlar tarafından paylaşılan tweetlerin işlevi değerlendirilirken, köşe yazıları içeren link paylaşımları ve doğrudan retweetler analize dâhil edilmemiştir. İşlev çalışmasında, yazarların kendi oluşturduğu içerikler, ifade ve yorum eklenen link paylaşımları ile tweet alıntılamalar incelenmiş̧ir.
} 
verdiklerini göstermesi açısından oldukça önemlidir. Konu dağılımda üçüncü sırada yüzde 11,4 (n=42) ile sağlıkla ilgili içerik paylaşımı gelmiştir. Dünyanın olağanüstü bir dönemden geçtiği ve Covid-19 salgınının hayatın her alanına olumsuz etkisi göz önüne alındığında sağıkla ilgili konuların köşe yazarlarının Twitter'da paylaştıkları içeriklerde sıklık olarak üçüncü sırada gelmesi olağan bir durum olarak değerlendirilebilir. Medya kategorisi içerisinde yer alan ve basın çalışanlarına, çeşitli programlara ve medyanın işleyişi ile konumuna odaklanan içeriklerin oranı ise yüzde 10,6 (n=39) olarak tespit edilmiştir. Gazetecilik mesleğinin bir alanı olarak köşe yazarlarının, Twitter'da basın çalışanlarına ve medyanın işleyişine dair konularda sıklıkla mesajlar paylaşmaları normal bir davranış olarak değerlendirilebilir. Covid-19 aşı çalışmalarına dair içerikler, çalışmada sağlık kategorisi içerisinde değil de ayrı bir kategoride değerlendirilmiştir. Covid-19 aşı çalışmaları başlığı altındaki konular, Twitter'da yazarların paylaştıkları içeriklerde yüzde 8,4 ( $n=31$ ) ile önemli bir oranı oluşturmuştur. Özellikle aşı çalışmalarına dair toplumda çeşitli yanlış bilgilerin dolaştığı düşünüldüğünde ve hem ülkemizde hem de uluslararası alanda salgın öncesi normale dönmenin bir yolu olarak aşı çalışmalarının önemli bir olgu olarak karşımıza çıkması, köşe yazarlarının bu konuya dair Twitter'da içerikler paylaşmalarına neden olduğu öne sürülebilir. Konu dağılımda, altıncı sırada yüzde 6 ( $n=22)$ ile kültürel konulardaki içerik paylaşımların gelmesi, köşe yazarlarının Twitter'ı yukarıda zikredilen konulardaki kadar yoğun bir şekilde olmasa da sinema, edebiyat ve sanat gibi faaliyetlerden bahsetmek için de kullandıklarını göstermektedir. Ekonomi konusunda yer alan içeriklerin oranı ise yüzde 4,6 ( $n=17)$ olmuştur. Analizde, yüzde 4,6 (n=17) oranındaki bir kısım, yapılan kategorilendirmede herhangi bir konu kategori içerisine dâhil edilemeyen bölümü oluşturmaktadır. Köşe yazarlarının, yukarıda yer alan konu alanlarının dışında, Twitter'da bahsettikleri diğer konuların oransal olarak dağılımları ise sırasıyla şu şekildedir: Yüzde 4,3 (n=16) çevre, yüzde 3,8 (n=14) demokrasi ve özgürlükler ile kişisel konular, yüzde 2,4 (n=9) konu yok kategorisi içerisinde yer alan kısa ifadeler, yüzde $2,1(n=8)$ seçim tartışmaları, yüzde 1,9 (n=7) savunma ve adalet, yüzde 1,4 (n=5) terör, yüzde 1,1 ( $n=4)$ bilim ve teknoloji ile tanıtım, yüzde 0,8 (n=3) eğitim, altyapı hizmetleri ve dini konular. Göçmenlik ve yolsuzluk konu kategorilerinde ise içerik paylaşımı tespit edilememiştir. 
Tablo 7 Köşe Yazarlarının Tweetlerinin Konuya Göre Dağılımı ${ }^{5}$

\begin{tabular}{lcc}
\hline & $\begin{array}{c}\text { FREKANS } \\
\text { (f) }\end{array}$ & $\begin{array}{c}\text { YÜZDE } \\
\text { (\%) }\end{array}$ \\
\hline Ekonomi & 17 & $\% 4,6$ \\
Sağlık & 42 & $\% 11,4$ \\
Eğitim & 3 & $\% 0,8$ \\
Politika & 59 & $\% 16$ \\
Kültürel faaliyetler & 22 & $\% 6$ \\
Covid-19 aşı çalışmaları & 31 & $\% 8,4$ \\
Çevre & 16 & $\% 4,3$ \\
Altyapı hizmetleri & 3 & $\% 0,8$ \\
Yolsuzluk & 0 & $\% 0$ \\
Demokrasi ve özgürlükler & 14 & $\% 3,8$ \\
Terör & 5 & $\% 1,4$ \\
Kişisel konular & 14 & $\% 3,8$ \\
Dışişleri & 52 & $\% 14,1$ \\
Göçmenlik & 0 & $\% 0$ \\
Savunma ve adalet & 7 & $\% 1,9$ \\
Medya & 39 & $\% 10,6$ \\
Seçim tartışmaları & 8 & $\% 2,1$ \\
Tanıtım & 4 & $\% 1,1$ \\
Dini konular & 3 & $\% 0,8$ \\
Bilim ve teknoloji & 4 & $\% 1,1$ \\
Konu yok (kısa ifadeler) & 9 & $\% 2,4$ \\
Diğerleri & 17 & $\% 4,6$ \\
\hline TOPLAM & 369 & $\% 100$ \\
\hline
\end{tabular}

\section{SONUÇ}

Toplumun en önemli kanaat önderlerinin başında gelen köşe yazarları, ifade ettikleri görüşleriyle toplumun düşünce yapısının şekillenmesinde ve kamuoyunun oluşumunda oldukça etkilidirler. Gerek geleneksel kitle iletişim süreci içerisindeki basılı gazetelerde gerekse online gazetelerdeki yazılarıyla, okurlarına çeşitli konularda fikir ve düşüncelerini iletirler. İnternet ve özellikle sosyal paylaşım ağların ortaya çıkmasıyla birlikte ise köşe yazarları, geleneksel anlamdaki basın-yayın sürecinin yanında bu ağlarda da okuyucularına/takipçilerine ulaşma imkânına kavuşmuşlardır. Sosyal ağların kullanıcı sayısı ve

\footnotetext{
${ }^{5}$ Yazarlar tarafından paylaşılan tweetlerin konu dağılımları saptanırken, köşe yazıları içeren link paylaşımları ve doğrudan retweetler analize dâhil edilmemiştir. Konu dağılımında yazarların kendi oluşturduğu içerikler, ifade ve yorum eklenen link paylaşımları ile tweet alıntılamalar incelenmiştir.
} 
yüksek etkileşim özelliği göz önüne alındığında, kanaat önderleri olarak köşe yazarlarının bu alanı nasıl ve ne şekilde kullandıklarının araştırılması önemli sonuçlar ortaya koymuştur. Bu çerçevede araştırma, örneklem olarak seçilen köşe yazarlarının Twitter'daki faaliyetlerine odaklanmıştır. Araştırma sonuçları değerlendirildiğinde, öncelikle dikkat çeken nokta reply $(\% 0,4)$ ve mention $(\% 5,9)$ oranlarının düşük olmasıdır. Diğer kullanıcılara cevap verme ve üretilen içeriklerde diğer kullanıcılardan bahsetme oranının düşük olması, köşe yazarları ve diğer kullanıcılar arasında yüksek bir etkileşimin gerçekleşmediği şeklinde yorumlanabilir.

Köşe yazarlarının Twitter'da oluşturdukları içeriklerin yaklaşık üçte biri özgün $(\% 31,5)$ yani kendi seslerinden oluşan mesajlardır. İ̧eriklerin yaklaşık üçte ikilik kısmı ise $(\% 68,5)$ doğrudan retweet, tweet alıntılama ve linklerden oluşmaktadır. Yorum eklemeden retweet oranının yüksek olması $(\% 26,2)$, köşe yazarlarının Twitter'da onayladıkları ve destekledikleri içerikleri takipçileriyle paylaştıklarını göstermektedir. Bu, yazarların takipçileri ve takip ettikleri içerik üreticileri arasında bir aracı görevi üstlendiklerinin işaretidir. Köşe yazarlarının, tweet alıntılama yoluyla $(\% 13,7)$ çeşitli kullanıcıların paylaştıkları içeriklere yorumlar ekleyerek takipçilerine aktarmaları ise kanaat önderleri olarak "News Curation" yöntemine yöneldiklerini göstermektedir. Köşe yazarlarının alıntıladıkları tweetlere daha çok pozitif yorumlar ekledikleri $(\% 55,9)$, negatif yorum ekleme oranının $(\% 40,2)$ daha az olduğu görülmüştür. Bu durum köşe yazarlarının daha çok onayladıkları, doğru olarak gördükleri, olumlu yaklaştıkları içeriklere kendi düşüncelerini ve bakış açılarını da ekleyerek takipçileriyle paylaştıklarını göstermektedir.

Köşe yazarlarının, Twitter'ın link paylaşım özelliğini önemli oranda kullandıkları görülmüştür. Yazarların Twitter'da oluşturdukları içeriklerin yüzde 28,6'ık kısmını link paylaşımları oluşturmaktadır. Burada dikkat çekici nokta, link paylaşımlarının neredeyse tamamına yakınının (\%88), Twitter takipçilerinin çevrimiçi ortamdaki köşe yazılarına ulaşmalarını sağlamak amacıyla paylaştıkları bağlantılar olmasıdır. Bu çerçevede yazarların Twitter'ı kullanarak, internet gazetelerindeki köşe yazılarının okunurluğunu artırmaya ve takipçilerinin köşe yazılarına ulaşımlarını kolaylaştırmaya çalıştıkları göstermektedir. Ayrıca, yazarların Twitter'da köşe yazılarına paylaştıkları linklerin neredeyse tamamına yakınında $(\% 97,4)$ kısa yorumlar ve spot ifadeler eklemeleri, yazdıkları konular hakkında ilgi uyandırarak daha fazla okuyucuya ulaşma çabasında bulunduklarının göstergesi sayılabilir. 
Twitter'da, yorum eklemeden veya yorumlar eklenerek paylaşılan içeriklerin kaynaklarına bakıldığında, yazarların kendi medyasından (köşe yazsına link ve kendi medyasından haber, bilgi ve yorum \%43,6) daha fazla içerik paylaştıkları görülmüştür. Daha sonra ağırlıklı olarak sosyal ağlardaki kişisel hesaplardan haber, bilgi ve yorum $(\% 36,9)$ paylaşmaktadırlar. Yazarların, internet gazetelerindeki köşe yazılarına erişim için paylaştıkları linkler hariç tutulduğunda, kendi medyalarından haber, bilgi ve yorum paylaşma oranı yüzde 10,9, kendi kurumu dışındaki profesyonel medyadan haber, bilgi ve yorum oranı yüzde 24,3 , çeşitli kurumsal web siteleri veya sosyal ağlardan haber, bilgi ve yorum yüzde 6,3, sosyal ağlardaki kişisel hesaplardan haber, bilgi ve yorum oranı ise yüzde 58,4'tür. Tablo 5'deki veriler göz önüne alındığında köşe yazarlarının Twitter'da, kendi medyaları haricinde profesyonel olan farklı medya kuruluşlarını da kaynak olarak kullanıp içerikler paylaşmaları; farkıı haber kaynaklarını da takip ettiklerini, önemli gördükleri içerikleri ya doğrudan ya da çeşitli şekillerde yorumlayarak takipçilerine sunduklarını göstermektedir. Ayrıca, yazarların çeşitli kaynaklardan içerik paylaşmaları, kanaat önderleri olarak farklı bakış açılarını ve fikirleri de takip edip, bunları kendi düşünce süzgeçlerinden geçirerek diğer bireylere aktardıklarına işaret etmektedir.

Yapılan analizde köşe yazarlarının Twitter kullanımları içerisinde en temel işlevlerinin, yüzde 41,8 ile kanaat (eleştiri \%33,1 - başkaları için destek \%7,3 - saldırı karşısında kendini savunma \%1,4) oluşturmak olduğu görülmüştür. Özellikle Twitter mesajları içerisinde eleştiri işlevi $(\% 33,1)$ taşıyan mesajların çoğunlukta olması, eleştirel düşüncede temel rol oynayan köşe yazarlarının Twitter'ı, mesleklerinin bir parçası olarak kullandıklarını göstermektedir. Ayrıca Twitter'da yazarların, çeşitli konularda bilgi vermeye de sıklıkla $(\% 20,3)$ yöneldiği belirlenmiştir. Twitter'ın yüksek etkileşime açık yapısı, son dakika gelişen olayları anında aktarabilme olanağı gibi avantajları, yazarların bu alanı çeşitli konularda bilgi vermek için kullanmalarını sağlamaktadır. Köşe yazarlarının Twitter'da yüzde 13 oranında analiz işlevinde bulundukları belirlenmiştir. Bu sonuç, yazarların Twitter'da çeşitli olay ve olguların nedenlerini, sonuçlarını ortaya koyarak, yanlı veya karşıt görüşler içermeyecek şekilde fikir beyan ettiklerini ve böylelikle takipçilerinin kendi kanaatlerini oluşturmalarına katkı sağladıklarını göstermektedir.

Köşe yazarlarının Twitter'da temel olarak hangi konulardan bahsettikleri incelendiğinde, tahmin edilebileceği üzere politik konular (\%16) ilk sırada yer almıştır. Çünkü, yazarların siyasi konulardaki yorum ve düşünceleri, bireylerin tutum ve davranışlarını etkileyen temel faktörlerden biridir. Twitter'da 
bahsedilen temel konular içerisinde dışişlerine dair bilgilerin $(\% 14,1)$ çoğunlukta olması ise, köşe yazarlarının sadece ülke gündemini değil uluslararası gündemi de takip ederek topluma bu konular hakkında düşünce ve kanaatlerini aktardıklarını kanıtlamaktadır. ${ }^{6}$ Yazarların, Twitter'da bahsettiği temel konular içerisinde üçüncü sırada sağlık kategorisinin gelmesi, dünyanın Covid-19 salgınıyla mücadele ettiği ve olağanüstü dönemlerden geçtiği bugünlerde oldukça olağandır. Bu yüzden gündemdeki konuların çeşidine göre (özellikle Covid-19 pandemisinin bitiminde ve ABD başkanlık tartışmaları sonrasında), farklı zaman dilimleri içerisinde yapılacak çalışmalarda farklı sonuçların çıkması beklenebilir.

\section{EXTENDED ABSTRACT}

The concept of "opinion leaders" emphasizes the view that interpersonal interaction is more effective than mass media in shaping individuals' attitudes and opinions. The most basic feature of opinion leaders is that they play an active role in shaping ideas during personal relationships. They are more involved in political debate, more concerned with public affairs, and they raised these things more during social relations than individuals who are not opinion leaders (Lazarsfeld et al., 1948, p.49)

"Two-stage flow theory", one of the subjects that researchers have been working on since the 1940s, has attracted more attention with the developing communication technologies, and many studies have been conducted on "Two-stage flow theory". With the emergence of social networking networks such as Facebook, Twitter and Instagram and their widespread use in society, the validity of the concept of opinion leaders in this new field of communication has been investigated.

Twitter has come to the fore with its features such as enabling interactive communication, and everyone announcing their ideas and participating discussions (Eren, 2015, p. 21-27), creating public opinion in very short periods of time (Yengin \& Bayrak, 2017, p. 382), making the thought publicized (Sayımer \& Çetinkaya, 2015, p. 227) and creating alternative news sources for the society (Çaba, 2019, p. 97). In this framework, it has begun to be questioned how, in what way and with what effect "opinion leaders" take part in this field.

\footnotetext{
${ }^{6}$ Özellikle yapılan analiz sırasında yazarların genellikle ABD başkanlık tartışmalarına dair bilgi verdikleri ve yorumlarda bulundukları görülmüştür.
} 
Columnists, who have the power of social influence (Altınoklu Şenay, 2016, p.120), interpreting various events and facts from different angles and presenting them to the readers (Dursun, 2015, p.2) fulfill an important mission. Moreover, columnists with their effectiveness in developing the culture of debate and informing the public correctly (Gölcü \& Yüksel, 2018, p. 790) fulling an important mission as a role in society. As opinion leaders, columnists fulfill an important function in shaping society's attitudes and behaviors. With the emergence and widespread use of social networking, columnists have had the opportunity to convey their feelings and thoughts on different issues to a much wider public with the content they share in these areas. In addition, the ability of readers / followers / viewers to express their opinions in a highly interactive environment by making positive or negative comments on the content shared by columnists on social networks can further affect the shaping of the opinions of readers / followers / viewers. At this point, it is important to examine how the columnists use Twitter, which has an effective power in today's communication structure. The main objective of the study in this context is to determine how, in what ways and what purposes columnists in Turkey use twitter. In addition, what their basic functions and which subjects in twitter they focus on are among the aims of the study. "Typical case sampling", which is one of the "purposeful sampling methods", was used in the study. Using this method, five people are selected among columnist who are still columnists in printed newspapers Turkey. The shares of five columnists, who are selected as a sample, on Twitter between 01.12.2020 and 31.01.2021 were analyzed using quantitative content analysis method. In the content analysis, the coding scheme developed by Noguera Vivo (2013, p. 107-109) and the categories created and used to determine the Twitter usage of opinion leaders participating in political discussion programs by Marcos-García et al. (2020, p. 281-283), were used. Research data were analyzed using SPSS 22 program. Results were evaluated by frequency analysis and percentage distribution.

In the study, 759 tweets shared by 5 columnists, who were selected as samples, over a twomonth period were analyzed. When the reply and mention rates are taken into consideration in the analysis, it has been observed that there is not a high interaction process between the columnists and other users on Twitter. It was determined that columnists used the direct retweet method in about a quarter of the content they shared. This shows that they act as an intermediary between their followers and the content producers they follow by sharing the content they approve and support on Twitter with 
their followers. In addition, it was determined that columnists used the tweet quoting method. By using this method they first added comments to the content shared by various users and then they conveyed these shared contents to their followers. This shows that as opinion leaders, columnists have turned to the "News Curation" method.

In the study, it was seen that columnists frequently use Twitter to link to their columns in online environments. This situation shows that the columnists try to increase the readability of their articles in internet newspapers by using Twitter, and they aim to make it easier for their followers to access their columns. When columnists' news and information sources on Twitter were examined, it was determined that the columnists also used different professional media organizations, which are apart from the media they work with, as a source and shared their content. Columnists also follow different news sources and when they see important contents, they convey these contents to their followers, but sometimes they first interpret these contents positively or negatively and then convey them to their followers. This situation shows that they, as opinion leaders, follow different perspectives and ideas and convey these perspectives and ideas to their followers after they pass them through their own thought filters. In addition, in the study, it was found that the three main functions that the columnists perform on Twitter are criticism, information and analysis. Finally, it was determined that columnists share the contents about policy, foreign affairs and health issues at a higher rate compared to other issues.

\section{KAYNAKÇA}

Adalat, M., Niazi, M. A., \& Vasilakos, A. V. (2018). Variations in power of opinion leaders in online communication networks. Royal Society Open Science, 1-23. doi:10.1098/rsos. 180642.

Altınoklu Şenay, M. N. (2016). Bir Alt Alan Olarak Köşe Yazarlığı. Galatasaray Üniversitesi Iletişim Dergisi, (25), 103-125. doi:10.16878/gsuilet.283059.

Bakan, U. (2017). Gazetecilerin alternatif bir medya olarak Twitter'ı kullanım düzeyi: Washington Post örneği. Iletişim Kuram ve Araştırma Dergisi(45), 263-287.

Balcı, Ş., \& Baloğlu, E. (2018). Sosyal medya bağımlıı̆̆ı ile depresyon arasındaki ilişki: "Üniversite gençliği üzerine bir araştırma". Galatsaray Üniversitesi Iletişim Dergisi, 209-234. doi:10.16878/gsuilet.500860.

Bamakan, S. M., Nurgaliev, I., \& Qu, Q. (2019). Opinion leader detection: A methodological review. Expert Systems with Applications(115), 200-222. doi:10.1016/j.eswa.2018.07.069. 
Bennett, W. L., \& Manheim, J. B. (2006). The one-step flow of communication. The ANNALS of the American Academy of Political and Social Science, 213-232. doi:10.1177/0002716206292266.

Bingöl, M., \& Yanık, H. (2020). Yerel yönetimlerde katılımcı demokrasi uygulamaları: Belediyelerin Facebook ve Twitter kullanım pratikleri üzerinden bir değerlendirme. Uluslararası Türk Kültür ve Sanatı Sempozyumu (s. 213-232). Ankara: Etimesgut Belediye Başkanlığı Kültür Yayınları.

Bohórquez-Pereira, G., Espinel, G. A., \& Mojica, E. C. (2020). Mujeres columnistas, liderazgos de opinión en un medio en línea colombiano. Cuadernos.info, 66-95. doi:10.7764/cdi.46.1731.

Büyüköztürk, Ş., Kılıç Çakmak, E., Akgün, Ö. E., Karadeniz, Ş., \& Demirel, F. (2020). Eğitimde bilimsel araştırma yöntemleri (29 b.). Ankara: Pegem Akademi.

Choi, S. (2015). The two-step flow of communication in Twitter-based public forums. Social Science Computer Review, 696-711. doi: 10.1177/0894439314556599.

Çaba, D. (2019). Sosyal medya çăğında gazetecilik ve inovasyon: Twitter'da gazetecilik pratikleri üzerine bir analiz. Ankara Üniversitesi ILEF Dergisi, 6(1), 95-120. doi: 10.1177/0894439314556599.

Çaba, D., \& Yeniçeri Alemdar, M. (2018). Kişisel markalama bağlamında gazetecilerin Twitter kullanımı. 16th International Symposium Communication in the Millennium CIM, (s. 660-679). Eskişehir.

Dursun, O. (2015). Köşe yazarlığından medya filozofluğuna: Ertuğrul Özkök ve Ahmet Hakan'ın köşe yazıları üzerine bir inceleme. Hacettepe Üniversitesi Sosyolojik Araştırmalar Dergisi (E-Dergi), 1-18.

Erdoğan, i. (2012). Pozitivist metodoloji ve ötesi, araştırma tasarımları niteliksel ve istatistiksel yöntemler (3 b.). Ankara: Pozitif.

Eren, B. (2015). Twitter ve siyasal iletişim. Selva Ersöz Karakulakoğlu, \& Özge Uğurlu (Ed.), Iletişim çalışmalarında dijital yaklaışmlar: Twitter içinde (s. 17-31). Ankara: Heretik Basın Yayın.

Good, R. (2016). The news curation workflow, process, key steps, skills of an online news curator. Erişim:medium.com/content-curation-official-guide/the-news-curation-workflow16301bbb5d32, Erişim tarihi: 18 Ocak 2021.

Gölcü, A., \& Yüksel, G. (2018). Siyasal partilerin ve liderlerin köşe yazılarında temsili. The Journal of International Social Research, 11(56), 771-791. doi:10.17719/jisr.20185639047.

Güz, N., \& Demirtaş, Z. G. (2019). Yeni medya çağında siyasi konuş̧ma ve kanaat önderliği: 24 Haziran Cumhurbaşkanlığı seçimi örneği. Yeni Medya(6), 80-98.

Güz, N., Yegen, C., \& Yanık, H. (2016). New media and journalism in Turkey: A Comparative analysis on Twitter usage practices of Yeni Şafak and Sözcü newspapers. Shaping the Future of News Media, 297-313.

Herkese açık ve korumalı tweetler hakkında. (2021, 5 Ocak). Erişim adresi: https://help.twitter.com/tr/safety-and-security/public-and-protected-tweets.

Hülür, H., \& Yaşın, C. (2019a). Küresel insanın hayal alanı olarak Twitter'ı anlamak. Himmet Hülür, \& Cem Yaşın (Ed.), Bilgi, Doğruluk ve Twitter içinde (s. 9-38). Ankara: Ütopya Yayınevi.

Hülür, H., \& Yaşın, C. (2019b). Twitter araştırmalarının bir panoraması. Himmet Hülür, \& Cem Yaşın (Ed.), Twitter Araştırmaları içinde (s. 9-42). Ankara: Ütopya Yayınevi. 
Katz, E. (1957). The two-step flow of communication: An up-to-date report on an hypothesis. Public opinion quarterly, 22(1), 61-78. doi:10.17719/jisr.20185639047.

Katz, E., \& Lazarsfeld, P. (1955). Personal Influence: The Part played by people in the flow of mass communication. New York.

Lazarsfeld, P. F., Berelson, B., \& Gaudet, H. (1948). The people's choice: How the voter makes up his mind in a presidential campaign. Columbıa University Press.

Marcos-García, S., Alonso-Muñoz, L., \& López-Meri, A. (2020). Extending influence on social media: The behaviour of political talk-show opinion leaders on Twitter. Communication \& Society, 277-293. doi:10.15581/003.33.2.277-293.

Noguera Vivo, J. M. (2013). How open are journalists on Twitter? Trends towards the end-user journalism. Communication \& Society/Comunicación y Sociedad, 26(1), 93-114.

Oeldorf-Hirsch, A., \& Sundar, S. S. (2015). Posting, commenting, and tagging: Effects of sharing news stories on Facebook. Computers in human behavior, 240-249. doi:0.1016/j.chb.2014.11.024.

Özkır, Y. (2016). Türkiye'de köşe yazarlığı olgusunun tarihsel izleği. Marmara Iletişim Dergisi(26), 37-53. doi:10.17829/midr.2017.43.

Park, C. S. (2013). Does Twitter motivate involvement in politics? Tweeting, opinion leadership, and political engagement. Computers in human behavior, 29(4), 1641-1648. doi:10.1016/j.chb.2013.01.044.

Park, C. S. (2018). Revisiting the Two-Step Flow Model on Twitter: Interconnection of Self-Identified South Korean Twitter opinion leadership, news consumption, news links, and news curation. sagepub.com/journals-permissions, Electronic News, 1-15. doi:10.1177/1931243118809780.

Picone, I. (2007). Conceptualising online news use. Observatorio (OBS*) Journal,3, 093-114.

Rogers, E. M. (2003). Diffusion of innovations (Fourth b.). New York: Free Press.

Sayımer, I., \& Çetinkaya, A. (2015). Alternatif medyanın Twitter'da gündem oluşturma süreci: Berkin Elvan olayı üzerine bir inceleme. Selva Ersöz Karakulakoğlu, \& Özge Uğurlu (Ed.), iletişim Çalışmalarında Dijital Yaklaşımlar: Twitter içinde (s. 225-258). Ankara: Heretik Basın Yayın.

Şahin, Ç. (2017). Verilerin analizi. R. Y. KIncal içinde, Bilimsel Araştırma Yöntemleri (s. 183-219). Ankara: Nobel Akademik Yayıncılık.

Tekinalp, Ş. (2008). Postmodernist dördüncü kuvvet: köşe yazarları. Istanbul Üniversitesi Illetişim Fakültesi Dergisi(31), 119-130.

Tokgöz, O. (2015). Temel gazetecilik (13 b.). Ankara: İmge Kitabevi.

Tosuner, A. (2015). İnternet aktivizminde Twitter'ın stratejik konumu. Selva Ersöz Karakulakoğlu, \& Özge Uğurlu (Ed.), iletişim çalışmalarında dijital yaklaşımlar: Twitter içinde (s. 117-143). Ankara: Heretik Basın Yayın.

Tsang, S. J., \& Rojas, H. (2020). Opinion leaders, perceived media hostility and political participation. Communication Studies, 71(5), 753-767. doi: 10.1080/10510974.2020.1791203. 
Weimann, G., Tustin, D. H., Van Vuuren, D., \& Joubert, J. P. (2007). Looking for opinion leaders: Traditional vs. modern measures in traditional societies. International Journal of Public Opinion Research, 19(2), 173-190. doi:10.1093/ijpor/edm005.

Wu, s., Hofman, J. M., Mason, W. A., \& Watts, D. J. (2011). Who says what to whom on Twitter. In Proceedings of the 20th international conference on World wide webs., 705-714. doi:10.1093/ijpor/edm005.

Yengin, D., \& Bayrak, T. (2017). Sosyal medyada dijital kamuoyu. The Turkish Online Journal of Design, Art and Communication, 7(2), 376-386. doi:10.7456/10702100/019.

Yıldırım, A., \& Şimşek, H. (2018). Sosyal bilimlerde nitel araştırma yöntemleri (11 b.). Ankara: Seçkin Yayıncilık. 